\title{
MSMEs Focus on Instagram Account Quality: Key Factors to Prioritize in Instagram Posting
}

\author{
Berto Mulia Wibawa ${ }^{1}$, Ninditya Nareswari ${ }^{2}$ \\ ${ }^{1,2}$ Department of Business Management, Institut Teknologi Sepuluh Nopember, Surabaya, 6011, email: \\ berto@mb.its.ac.id ${ }^{1}$, nindityanareswari26@gmail.com²
}

Diterima: 08/08/2019

Direview: 18/10/2019

Diterbitkan: 28/11/2019

Hak Cipta @ 2019 oleh Penulis (dkk) dan Jurnal Sosial Humaniora (JSH)

*This work is licensed under the Creative

Commons Attribution International License (CC

BY 4.0).

http://creativecommons.org/licenses/by/4.0/

\section{Open Access}

\section{Introduction}

\section{Subject Area: Entrepreneur (Enterpreneur)}

\begin{abstract}
Nowadays, most of MSMEs have a quite good understanding of social media and how it works for their business. In Indonesia, Instagram is one of the best powerful tools to introduce and market their product instantly. However, social commerce face problems especially in customer trust. It is suspected customers are doubt to the key factors of social media online shop, i.e.: reputation, transaction, communication, safety, information quality, economic feasibility, and word-of-mouth referrals. The purpose of this study is to test a framework of Instagram account quality model and its impact on MSMEs social media marketing strategy. An online-based questionnaire was administered to 271 MSMEs. Furthermore, structural equation modeling was used to analyze the data. Findings indicated that there are significant effects of information quality, reputation, safety, communication, and economic feasibility on the Instagram account quality construct. The practical implications that need to be emphasized on MSMEs is the need to develop their information quality on Instagram. It is important because it is the most significant factor towards Instagram account quality in online store perception. A focus on improving information quality will also help MSMEs to communicate and promote their post to reach more audience and interaction with potential consumers.
\end{abstract}

Keywords: Instagram account quality; customer trust; MSMEs; Instagram; key factors

Recently, there are so many Micro Small Medium Enterprises (MSMEs) in Indonesia, both registered and unregistered. They usually operate on a small scale with limited networks and clusters, but contribute significantly to Indonesian economic growth (OCED, 2018). As new technologies adopted by MSMEs, currently the use of social media plays an important role in MSMEs marketing activities. Most of them have a quite good understanding of social media or social commerce and how it works for their business (AlSharji et al, 2018). In Indonesia and several developing countries, Instagram noted as one of the best powerful tools to introduce and market their product instantly. According Duggan (2015), Instagram is one of the most prospective growing social media platform. Supported by more than 56 million active monthly account, Indonesia has largest potential online market in Asia Pacific (Statista, 2019). However, social commerce activity face problems especially in customer trust while happened during online shopping transaction and interaction with MSMEs (Kim \& Park, 2013). The rise of online shopping fraud has impacted on decreasing 
consumer reliance, especially to the recent MSMEs which not yet have a good reputation in the internet (Hamouda, 2018).

Considerable evidence had been founded on MSMEs behavior in using social media (Rahbi \& Abdullah, 2017) (Ainin et al, 2015) (Kim \& Park, 2013). Surprisingly, there is still lack research investigating key factors among MSMEs in developing countries, peculiarly Indonesia that have most MSMEs in South East Asia. Therefore, this study aims to investigate the key factors influencing MSMEs Instagram account quality using modified s-commerce characteristics model developed particularly by Kim \& Park (2013). Based on hypotheses development which noted to previous study, it is predicted that reputation, transaction, communication, safety, information quality, economic feasibility, and word-of-mouth referrals directly affect Instagram account quality.

\section{Literature Review}

Social media is a tool that used by MSMEs for marketing activity. According to Jones,et al (2015) showed that social media can increase brand awareness, better relationship with customer and sales in small business. In line with Lipiäinen and Karjaluoto (2015) showed that speed of communication, cost savings, and changing customer behavior are the reasons why MSMEs use digital marketing. There are many factors that impact social media performance on MSMEs. Based on Dutot and Bergeron (2016), entrepreneurial orientation and customer orientation have a positive impact on sales and business development which in turn has a positive impact on social media performance.

Social media is an important tool for marketing activity because it allows businesses to listen and learn from their customers in a way they have never been able to do before (Jones et al 2015), so MSMEs can build their reputation based on that information. Moreover, social media enables firms to get potential customers at relatively low cost and higher levels of efficiency than with more traditional communication tools especially in small business (Cox, 2012). Social media can use for one way and two way communication, so it's effective to enhance communication between the customers and MSMEs. In addition social media can be used for distribute their information. The internet usage nowadays change the way business share their information. (Jones, et al 2015). Consequently, it change the way consumer search for information too. So, the most important things for social media marketing is to provide the trusted information for instance, how to buy or make online transaction, the competitive price offered, and the safety of online shopping. These things can impact the decision of potential buyer, so these can be a key of social media quality especially in instagram account. Based on the literature, the following hypothesis are proposed

H1: Reputation has a positive effect on instagram account quality

$\mathrm{H} 2$ : Transaction has a positive effect on instagram account quality

H3: Communication has a positive effect on instagram account quality

H4: Safety has a positive effect on instagram account quality

H5: Information quality has a positive effect on instagram account quality

H6: Economic feasibility has a positive effect on instagram account quality

H\&: WOM referral has a positive effect on instagram account quality 


\section{Method}

A quantitative conclusive-descriptive approach was the main method used for data analysis, which is completed by a survey with an online-based questionnaire. The survey was conducted among MSMEs in East Java, Indonesia, from January to February 2019. 500 questionnaires were distributed to the MSMEs business owner/manager using email, social media, and instant messenger, supported by the database given by Ministry of Cooperatives Small and Medium Enterprises Republic of Indonesia. Criteria of MSMEs in this research are having monthly income above IDR 10.000 .000 and currently operating Instagram account for their firms with minimum 10 posts per month, in the last 6 months. Therefore, after the screening phase, only 271 questionnaires were meet the criteria and included in the data analysis. The questionnaire was developed in Indonesian language, and divided into three sections: (1) demographics, (2) questions related to social media usage, and (3) Instagram account quality factors. Questions related to the Instagram account quality and its factors were assessed on a seven-point Likert scale of strongly disagree (1) to strongly agree (7).

Based on Wibawa and Bramanti (2018), data analysis involves three stage processes. First, descriptive analysis was used to understand the demographics and social media usage of the MSMEs. Second, convergent validity and reliability test were assessed to evaluate the measurement model using three indicators: (1) average variance extracted (AVE), (2) construct reliability (CR), and (3) cronbach's alpha. Finally, structural equation modeling (SEM) analysis were performed to examine the relationship between proposed variables. The Structural Equation Modeling analysis was employed with AMOS to validate the measurement model. SEM method was selected because it can be displayed in visual interactive form (path diagram) and also additional advantages such as more explicit of measurement error, calculation of unobserved variables by observed variables, and of course model testing to fit of the data (Byrne, 2012).

The research model underline on determining key factors and to understand the most important factors contributed to the Instagram account quality for MSMEs, so in the future MSMEs will know what factors to prioritize when optimizing the use of Instagram for market their product. Seven hypotheses based on previous research (Kim \& Park, 2013; Park et al., 2012; Lu et al., 2006; Kim et al., 2008; Cheung \& Lee, 2006; Park \& Kang, 2003; Grewal et al, 1998; Kuan and Bock, 2007) are developed (Figure 1).

\section{Result and Discussion}

Table 1 shows the demographic characteristics of the respondents. Total of respondents were 271 respondents. Based on law in Indonesia about MSMEs (UU No 20 Tahun 2008), MSMEs were divided into 3 category: 1. Micro: enterprise with a maximum IDR 300 million in annual income, and IDR 50 million in net assets, 2. Small: enterprise with a maximum IDR 2,5 billion in annual income, and IDR 500 million in net assets, 3. Medium: enterprise with a maximum IDR 50 billion in annual revenue, and IDR 10 billion in net assets. As shown in table 1, more than half MSMEs (142 enterprises) were in small category $(52,40 \%)$ and the rest were in micro category $(25,83 \%)$ and medium category $(21,77 \%)$. Most respondents were owner of the MSMEs $(82,29 \%)$ and the rest were the manager $(14,76 \%)$ and other $(2,95 \%)$. The type of industry was divided into seven categories: Food and beverage (50,55\%), Fashion $(8,86 \%)$, handy craft/art $(5,90 \%)$, service $(12,18 \%)$, retailer $(15,50 \%)$, grocery $(4,43 \%)$, and others $(2,58 \%)$. Most of MSMEs were classified as food and beverage category (137 enterprises). The operating year of MSMEs were divided into seven 
categories: less than 1 year $(15,13 \%), 1-5$ years $(48,34 \%), 5-10$ years $(24,72 \%)$, and more than 10 years $(11,81 \%)$

Figure 1. The research model with hypotheses

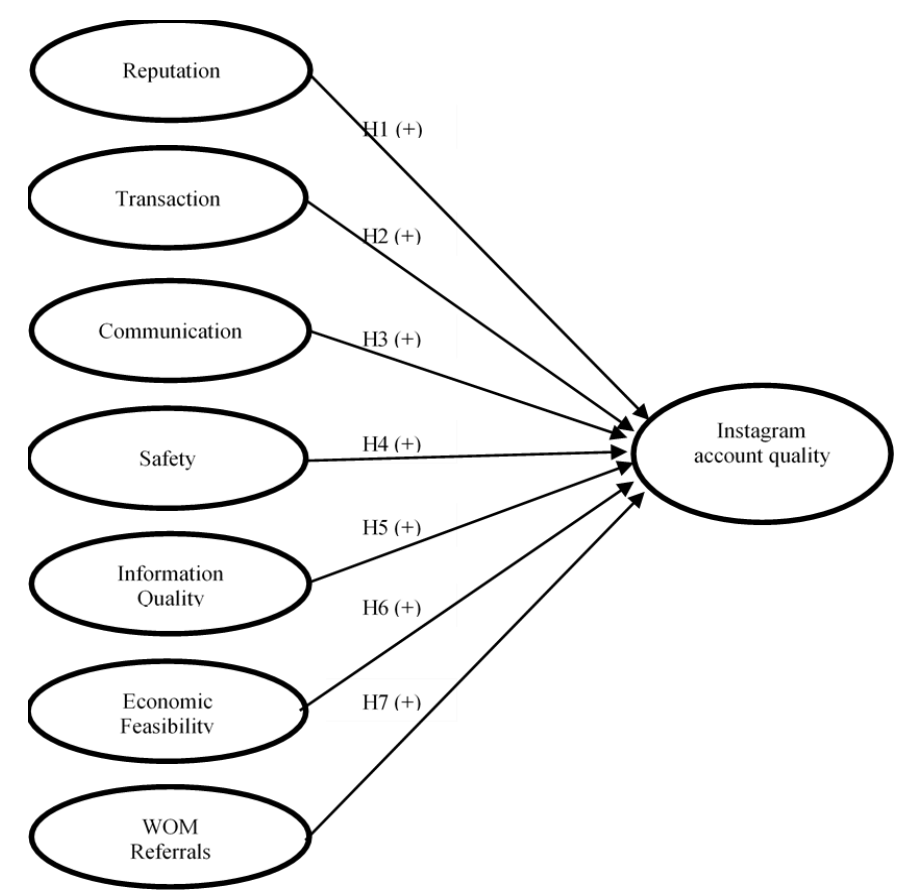

The validity and reliability test were conducted to evaluate the measurement of the model. The convergent validity was tested by average variance extracted (AVE) and the construct reliability was tested by composite reliability (CR) and Cronbach's alpha. As shown in Table 2, all AVEs were above 0.5 indicates an acceptable model and all alphas values and composite reliability values exceed 0.7 , which indicated that the reliability of each construct was reasonably satisfied (Table 2). Table 3 shows the goodness of fit for the model. Most of the fit measurements show good fit results except GFI and NFI, however the measured model is still acceptable (Table 3).

TABLE 1. DEMOGRAPHIC CHARACTERISTICS OF MSME

\begin{tabular}{llrr}
\hline \multicolumn{1}{c}{ Demographic characteristic } & \multicolumn{1}{c}{ Categories } & $\begin{array}{c}\text { Frequency } \\
\text { N=271 }\end{array}$ & $\begin{array}{c}\text { Percentage } \\
(\%)\end{array}$ \\
\hline Firm type & Micro & 70 & 25,83 \\
& Small & 142 & 52,40 \\
Status & Medium & 59 & 21,77 \\
& Owner & 223 & 82,29 \\
Type of industry & Manager & 40 & 14,76 \\
& Other & 8 & 2,95 \\
& Food and beverage & 137 & 50,55 \\
& Fashion & 24 & 8,86 \\
& Handy craft/art & 16 & 5,90 \\
& Service & 33 & 12,18 \\
Operating year & Retailer & 42 & 15,50 \\
& Grocery & 12 & 4,43 \\
& Other & 7 & 2,58 \\
& <1 year & 41 & 15,13 \\
& 1-5 year & 131 & 48,34 \\
& 5-10 year & 67 & 24,72 \\
& >10 year & 32 & 11,81 \\
\hline
\end{tabular}


TABLE 2. CONVERGENT VALIDITY AND RELIABILITY TEST

\begin{tabular}{lcccc}
\hline \multicolumn{1}{c}{ Latent variable } & No of items & AVE & CR & Cronbach's Alpha \\
\hline Reputation & 3 & 0.80 & 0.88 & 0.87 \\
Transaction & 4 & 0.69 & 0.83 & 0.85 \\
Communication & 4 & 0.78 & 0.85 & 0.84 \\
Safety & 4 & 0.82 & 0.89 & 0.92 \\
Information quality & 4 & 0.88 & 0.91 & 0.94 \\
Economic feasibility & 4 & 0.77 & 0.84 & 0.88 \\
WOM referrals & 3 & 0.71 & 0.81 & 0.90 \\
Instagram account & 3 & 0.88 & 0.90 & 0.92 \\
quality & & & & \\
\hline
\end{tabular}

TABLE 3 GOODNESS OF FIT

\begin{tabular}{|c|c|c|c|c|}
\hline No & GOF Measurement & Cut-off Value & Score & Result \\
\hline \multicolumn{5}{|c|}{ Absolute Fit Indices } \\
\hline 1 & CMIN/DF & $\leq 3$ & 2.96 & Good fit \\
\hline 2 & GFI & $\geq 0.9$ & 0.88 & Marginal fit \\
\hline 3 & AGFI & $\geq 0.9$ & 0.90 & Good fit \\
\hline 4 & RMR & $\leq 0.08$ & 0.07 & Good fit \\
\hline 5 & RMSEA & $<0.08$ & 0.07 & Good fit \\
\hline \multicolumn{5}{|c|}{ Incremental Fit Indices } \\
\hline 6 & NFI & $\geq 0.9$ & 0.88 & Marginal fit \\
\hline 7 & CFI & $\geq 0.9$ & 0.94 & Good fit \\
\hline 8 & TLI & $\geq 0.9$ & 0.93 & Good fit \\
\hline \multicolumn{5}{|c|}{ Parsimony Fit Indices } \\
\hline 9 & PNFI & $0.60-1.00$ & 0.79 & Good fit \\
\hline 10 & PGFI & $0.50-1.00$ & 0.75 & Good fit \\
\hline
\end{tabular}

The structural equation modeling (SEM) analysis were conducted to examine the relationship between proposed variables. Table 4 presents the result of the hypothesis testing. Hypothesis 1 predicts reputation has a positive effect on instagram account quality. Table 4 shows that reputation has a significant positive effect on instagram account quality $(\beta=0.84, \mathrm{p}<0.05)$, which provides support for H1. Based on $\beta$ score, reputation was the second priority of instagram account quality. According to Doney \& Cannon (1997), a firm with good reputation is honest, well known, and concerned about its customer. In addition, a good reputation is a valuable intangible asset for the firm. Good reputation can enhance customer trust and was reflected on instagram account quality. Mostly, MSMEs still operate at a young age (1-5 years). The potential buyers may never hear about the MSME's reputation before. So, the MSMEs can show their reputation via instagram posting to enhance the potential customer.

TABLE 4 HYPOTHESIS TESTING

\begin{tabular}{|c|c|c|c|c|c|c|c|c|}
\hline \multirow{2}{*}{$\begin{array}{l}\text { No. } \\
\text { H1 }\end{array}$} & \multicolumn{3}{|c|}{ Hypotheses testing } & \multirow{2}{*}{$\begin{array}{c}\boldsymbol{\beta} \\
0.84\end{array}$} & \multirow{2}{*}{$\begin{array}{c}\begin{array}{c}P \text { - } \\
\text { value }\end{array} \\
* * *\end{array}$} & \multirow{2}{*}{$\begin{array}{c}\text { Note } \\
\text { Significant }\end{array}$} & \multirow{2}{*}{$\begin{array}{c}\text { Result } \\
\text { Accepted }\end{array}$} & \multirow{2}{*}{$\begin{array}{c}\begin{array}{c}\text { Key factors } \\
\text { priority using } \\
\text { score }\end{array} \\
2\end{array}$} \\
\hline & Reputation & 7 & Instagram account quality & & & & & \\
\hline $\mathrm{H} 2$ & Transaction & 7 & Instagram account quality & 0.32 & 0.418 & $\begin{array}{c}\text { Not } \\
\text { significant }\end{array}$ & Rejected & - \\
\hline $\mathrm{H} 3$ & Communication & 8 & Instagram account quality & 0.71 & $* * *$ & Significant & Accepted & 4 \\
\hline $\mathrm{H} 4$ & Safety & 8 & Instagram account quality & 0.80 & $* * *$ & Significant & Accepted & 3 \\
\hline H5 & $\begin{array}{l}\text { Information } \\
\text { quality }\end{array}$ & 8 & Instagram account quality & 0.90 & $* * *$ & Significant & Accepted & 1 \\
\hline H6 & $\begin{array}{l}\text { Economic } \\
\text { feasibility }\end{array}$ & 8 & Instagram account quality & 0.67 & $* * *$ & Significant & Accepted & 5 \\
\hline $\mathrm{H} 7$ & WOM refferals & 8 & Instagram account quality & 0.34 & 0.231 & $\begin{array}{c}\text { Not } \\
\text { significant }\end{array}$ & Rejected & - \\
\hline
\end{tabular}

Note:

- *** : significant at $\mathrm{p}$-value $<0.05$ 
Hypothesis 3 predicts communication has a positive effect on instagram account quality. As shown in Table 4, communication has a significant positive effect on instagram account quality $(\beta=0.71, \mathrm{p}<0.05)$. This finding supports $H 3$, which suggest that communication reflects the instagram account quality. Based on $\beta$ score, communication was the fourth priority of instagram account quality. The marketing communication refers to the means adopted by the firms to deliver messages about the products and the brands they sell to the customers with the intention to persuade them to purchase. The goal of communication is not just to induce initial purchase but also to achieve post purchase satisfaction (Kerin and Peterson, 2007). One of the reasons why MSMEs use instagram on their business was to build interactions to their customers. In addition, Park and Kang (2003) claimed that communication was a key driver of active online communities and that consumers who shared experiences and information were more likely to trust in online firms. Therefore, MSMEs can build the communication more effective via instagram posting to enhance the customer's trust.

Hypothesis 4 predicts safety has a positive effect on instagram account quality. The result shows that safety has a significant positive effect on instagram account quality $(\beta=0.80, \mathrm{p}<0.05)$ which provides support for H4. Based on on $\beta$ score, safety was the third priority of instagram account quality. According to Liaou and Lin (2006) consumers tend to avoid the risk rather than maximize utility with higher risk. In spite of the limited information, potential buyers still doubt about the safety shopping in MSMEs. In addition, not only the customers, but also the seller face the risk in online shopping, for example getting loss from fraud. So, both consumers and seller can use instagram to ensure a safe shopping experience. Therefore, safety is one of the key factor's instagram account quality.

Hypothesis 5 predicts information quality has a positive effect on instagram account quality. As shown in table 4 , information quality has a significant positive effect on instagram account quality $(\beta=0.90, p<0.05)$ which provides support for H5. As shown in table 4, the highest $\beta$ score was the information quality (0.90). This means the information quality was the most important factor that affect instagram account quality. Information quality refers to the latest, accurate, and complete information provided by a website to its users. (Kim \& Park, 2013). Information quality included the accuracy, validity and availability information about particular product or service that customers want to purchase with hypothesis 5 , the reason customers open firm's instagram profile is to get information that they need. Online buyers mostly depend on information provided because they have limited sources of information. Mostly, MSMEs aren't known by their potential buyers because they don't implement promotional activities as high as big company, so the information are limited and can't reach their potential buyers. It means MSMEs should maximized their instagram account by enhance the information quality.

Hypothesis 6 predicts economic feasibility has a positive effect on instagram account quality. The result shows that economic feasibility has a significant positive effect on instagram account quality $(\beta=0.67, \mathrm{p}<$ 0.05). This finding support $\mathrm{H} 6$ which suggest that economic feasibility. Based on $\beta$ score, economic feasibility was the fifth priority of instagram account quality. Economic feasibility is defined as the value that an individual abandons or sacrifices to acquire a particular product or service (Grewal, Monroe, \& Krishnan, 1998; Monroe \& Krishnan, 1983). According to Oh Yoon \& Lee (2006), low-priced products or service are 
one of the most important benefits of online shopping. Therefore, they can increase the level of consumer's trust in online firms. So MSMEs can enhance the instagram account quality by show their low-priced products. As shown in Table 4, all of the hypothesis were supported except the hypothesis 2 and hypothesis 7 . There are no significant effect between transaction and WOM referrals on instagram account quality. It means transaction and WOM referrals are not the key factors of instagram account quality.

In summary, findings indicate that there are significant effect between information quality, reputation, safety, communication, and economic feasibility to the Instagram account quality construct. The practical implications emphasize on MSMEs first need to develop their information quality on Instagram, because that is the most significant factors towards Instagram account quality in online store perception. Audience will come to follow up account with good information quality, in this case for example: clear product details (size, dimensions, weight, best before, etc), how to order, how to user product, warnings, customer care, and after sales service. A focus on improving information quality will also help MSMEs to communicate and promote their post to reach more audience and interaction with potential consumers. After information quality is much better and able to gain consumers attention, then MSMEs should improve the second factor which is reputation in order to make sure their Instagram account is (1) well known (marked by number of followers and wide interactions); (2) good reputation (positive comments and build up a good profile); and (3) honest. Safety is the third most important factor, make sure that transaction and data security are guaranteed by the firm, while communication factor related to how to present the information to the consumer stands after it. Lastly, economics feasibility becomes the fifth most important factor that contributes to instagram account quality. MSMEs should not only offer attractive and valuable products, but also must think about reasonable price and make consumers happy with beyond expectations experience. About price, these days many of MSMEs set their product price almost the same as well-known branded price. This situation is not suitable because in essence and reality, MSMEs must offer something that is cheaper than branded products.

\section{Conclusion}

This study examined the key factors influencing MSMEs Instagram account quality using modified scommerce characteristics model developed particularly by Kim \& Park (2013). This study extended the previous literature about s-commerce and the use of instagram for MSMEs. Using 271 MSMEs in East Java, Indonesia, the results of this study showed the significant effect between reputation, communication, safety, information quality, and economic feasibility on the instagram account quality construct. This study also showed the information quality was the most important key on instagram account quality. Based on MSMEs condition in Indonesia, their potential buyers still have limited information about them. On the other hand, Indonesia ranks fourth as the country with the most number of Instagram accounts (Statista, 2019). So, MSMEs can improve their information quality in their instagram posting to enhance the potential buyers and trust.

This study has some limitations that present opportunities for future research. First, this study examined all of MSMEs aggregately without divided it into three categories which has different characteristic for each categories. So, the future research should divide the sample based on types of MSMEs. Second, this study only captured the online store perception, not the customer perception. For the future research can capture the 
customer perception. Third this study used cross section data that only captured a single point in time, not over time. For the future research, it is recommended to use longitudinal data to minimize the potential biases.

\section{Acknowledgement}

This research was fully funded by Institut Teknologi Sepuluh Nopember (ITS), with young researcher funding scheme. We thank our colleagues from Department of Business Management, especially Entrepreneurship and Small Medium Enterprises Development (ESME) Laboratory that greatly assisted the research surveys and data analysis.

\section{References}

AlSharji, A., Ahmad, S. Z., \& Abu Bakar, A. R. (2018). Understanding Social Media Adoption in Smes: Empirical Evidence fom The United Arab Emirates. Journal of Entrepreneurship in Emerging Economies, 10(2), 302-328.

Byrne, B. M. (2012). Multivariate Applications Series. Structural Equation Modeling with Mplus: Basic Concepts, Applications, and Programming. New York, NY, US: Routledge/Taylor \& Francis Group.

Cheung, M. k., \& Lee, M. K. O. (2006). Understanding Consumer Trust in Internet Shopping: A Multidisciplinary Approach. Journal of the American Society for Information Science and Technology, 57(4), 479-492.

Cox, Sarah (2012). Social Media Marketing in a Small Business: A Case Study Department of Computer Graphics Technology Degree Theses, Retrieved from: http://docs.lib.purdue.edu/cgttheses/16

Doney, P. M., \& Cannon, J. P. (1997). An Examination of the Nature of Trust in Buyer-Seller Relationships. Journal of Marketing, 61(2), 35-51.

Duggan, M. (2015), Mobile Messaging and Social Media 2015, Pew Research Center, Retrieved from: www.pewinternet.org/files/2015/08/Social-Media-Update-2015-FINAL2.pdf

Dutot, V. \&Bergeron, F. (2016), From Strategic Orientation to Social Media Orientation. Improving SMEs' Performance on social Media. Journal of Small Business and Enterprise Development,Vol. 23 No. 4, pp. 1165-1190.

Grewal, D., Monroe, K. B., \& Krishnan, R. (1998). The Effects of Price-Comparison Advertising on Buyers' Perceptions of Acquisition Value, Transaction Value, and Behavioral Intentions. Journal of Marketing, 62(2), 46-59.

Hamouda, M. (2018). Understanding Social Media Advertising Effect on Consumers' Responses: An Empirical Investigation of Tourism Advertising on Facebook. Journal of Enterprise Information Management, 31(3), 426-445.

Jones, N., Borgman, R. and Ulusoy, E. (2015), "Impact Of Social Media on Small Businesses", Journal of Small Business and Enterprise Development, Vol. 22 No. 4, pp. 611-632. https://doi.org/10.1108/JSBED-09- 2013-0133

Kerin, R. A. and Peterson, R. A., (2007). "Strategic Marketing Problems. Cases and Comments". Prentice Hall: New York, pp 263 
Kim, D. J., Ferrin, D. L., \& Rao, H. R. (2008). A Trust-Based Consumer Decision-Making Model in Electronic Commerce: The Role of Trust, Perceived Risk, and Their Antecedents. Decision Support Systems, 44(2), 544-564.

Kim, Y.H. (2011). Market Analysis and Issues of Social Commerce in Korea, KISDI, 23(11), 41-63.

Kim, S., \& Park, H. (2013). Effects of Various Characteristics of Social Commerce (S-Commerce) On

Consumers' Trust and Trust Performance. International Journal of Information Management, 33(2), 318-332.

Kuan, H. H., \& Bock, G. W. (2007). Trust Transference in Brick and Click Retailer: An Investigation of the Before-Online-Visit Phase. Information \& Management, 44(2), 175-187.

Liao, C., Palvia, P., \& Lin, H. N. (2006). The Roles of Habit and Web Site Quality in E-Commerce. International Journal of Information Management, 26(6), 469-483.

Lipiäinen, Heini Sisko Maarit., \& Karjaluoto Heikki. (2015). The Usage of Digital Marketing Channels in Smes, Journal of Small Business and Enterprise Development, Vol. 22 Iss 4 pp. -

Lu, Y.-B., Deng, Z-Ch., \& Yu, J.-H. (2006). A Study on Evaluation Items and Its Application for B2C ECommerce Trust. In Proceedings of Management Science and Engineering International Conference Lille, Nord-Pas-de-Calais, France.

Monroe, K. B., \& Krishnan, R. (1983). A Procedure for Integrating Outcomes across Studies. Advances in Consumer Research, 10, 503-508

OECD. (2018), SME and Entrepreneurship Policy in Indonesia 2018, OECD Studies on SMEs and Entrepreneurship, OECD Publishing, Paris, https://doi.org/10.1787/9789264306264-en.

Oh, J. H., Yoon, Y. S., \& Lee, K. Y. (2006). An Empirical Study on the Determinants of Trust and Purchasing Intention in Online Shopping. Korea Industrial Economics Association, 19(1), 205-224.

Park, J., Gunn, F., \& Han, S. L. (2012). Multidimensional Trust Building in E-Retailing: Cross-Cultural Differences in Trust Formation and Implications for Perceived Risk. Journal of Retailing and Consumer Services, 19(3), 304-312.

Park, C., \& Kang, B. G. (2003). Factors Influencing On Trust toward E-Commerce by Consumer Experience of Online Buying. Information Systems Review, 5, 81-95.

Pemerintah Indonesia. 2008. Undang-Undang No. 11 Tahun 2008 Yang Mengatur Tentang Usaha Mikro Kecil Menengah. Lembaran Negara RI Tahun 2008, No. 20. Sekretariat Negara. Jakarta.

Rahbi, A. L., \& Abdullah, H. S. (2017). Factors Influencing Social Media Adoption in Small and Medium Enterprises (Smes) (Doctoral Dissertation, Brunel University London).

Statista. (2019, June 12). Countries with the most Instagram users 2019. Retrieved from: https://www.statista.com/statistics/578364/countries-with-most-instagram-users/.

Wibawa, B., \& Bramanti, G. (2018). Analisis Model Struktural Faktor-Faktor Pembentuk Fashion-Oriented Impulse Buying Produk Ritel Fashion Berdasarkan Sudut Pandang Konsumen Usia Remaja [Structural Model Analysis of Fashion-Oriented Impulse Buying of Retail Products Based on the Teenage Customer's Perspective]. DeReMa (Development Research of Management): Jurnal Manajemen, 13(1), 55-82. doi:http://dx.doi.org/10.19166/derema.v13i1.790 